\title{
Clefted Lymphocytes Count
}

National Cancer Institute

\section{Source}

National Cancer Institute. Clefted Lymphocytes Count. NCI Thesaurus. Code C147387.

The determination of the amount of cryofibrinogen present in a sample. 